\begin{tabular}{lrl}
\hline \hline VOLUME 1 & Number 1 & Page 21 - 30 \\
\hline \hline
\end{tabular}

\title{
Analisis Campur Kode Bahasa Indonesia dan Bahasa Kutai di Kalangan Pedagang Pasar Gerbang Raja Mangkurawang Kecamatan Tenggarong
}

\author{
Rika Oktavia, Meita Setyawati, Kukuh Elyana \\ Universitas Mulawarman \\ Universitas Mulawarman \\ Universitas Mulawarman \\ Email: rikaoktavia776@gmail.com
}

\begin{abstract}
This study aims to describe the form of code mixing between Indonesia and Kutai languages as well as the factors behind the occurred among traders at Pasar Gerbang Raja Mangkurawang, Tenggarong district. The analysis method used in this study is the contextual method. This research is a qualitative research, where the research that produces descriptive data in the form of written words. The data collection techniques used werw listening, recording and interviewing techniques. Based on the data analysis, it was found that the form of code mixing included the insertion of elements in the form of 28 words, 2 phrases and 1 clause. The background for the occurrence of code mixing is due to two factors, namely the speaker factor and the language factor. Speakers factor that causes code mixing, due to relaxedness and habits in language. Meanwhile, the linguistic factor is because speakers consider words from regional languages more refined.
\end{abstract}

Keywords: code mix, kutai language, indonesian.

\section{PENDAHULUAN}

Bahasa merupakan alat yang digunakan oleh manusia untuk berkomunikasi satu dengan yang lainnya dan mempunyai peranan yang penting bagi kehidupan manusia. Dengan menguasai bahasa seseorang dapat melakukan proses komunikasi, baik dalam bentuk lisan maupun tulisan. Dalam proses komunikasi tersebut, seseorang tidak hanya menggunakan satu bahasa saja. Pada umumnya dalam konteks masyarakat Indonesia yang dwibahasawan, seseorang akan memahami minimal dua bahasa yang terdiri dari bahasa daerah sebagai B1 dan bahasa Indonesia sebagai B2.

Kridalaksana (1982: 17) mendefinisikan bahasa adalah sistem lambang yang arbitrer yang dipergunakan oleh suatu masyarakat untuk bekerja sama, berinteraksi dan mengidentifikasi diri. Fungsi dari bahasa adalah sebagai alat untuk berinteraksi atau berkomunikasi dan juga sebagai alat untuk menyampaikan pikiran, gagasan, konsep, atau juga perasaan (Chaer dan Agustina, 2010: 14). Oleh sebab itu, ketepatan bahasa sangat diperlukan demi kelancaran berkomunikasi. Sering ditemukan orang bertutur dengan menggunakan bahasa daerah tertentu tiba-tiba mengganti bahasanya atau mencampur bahasa daerah dengan bahasa Indonesia sesuai keperluannya. Biasanya pencampuran bahasa terjadi pada situasi nonformal, seperti halnya di kalangan pedagang. Adanya penggunaan unsurunsur bahasa lain ketika memakai bahasa tertentu tanpa adanya maksud dan tujuan dalam percakapan disebut campur kode.

Pasar merupakan tempat bertemunya pedagang dan pembeli untuk melakukan interaksi jual beli. Pilihan bahasa sangat penting untuk melakukan interaksi jual beli. Pilihan bahasa oleh masyarakat tutur di pasar tidak pernah lepas dari situasi sosial yang ada di sekitarnya. Pedagang 
dan pembeli tidak selalu berasal dari lingkungan yang sama. Perbedaan ini lah yang menimbulkan usaha kesepakatan terhadap penggunaan bahasa, yang kemudian menciptakan pilihan-pilihan berbahasa yang sesuai dengan situasi. Pasar Gerbang Raja Mangurawang yang berada di daerah Tenggarong dijadikan lokasi penelitian, karena pasar Gerbang Raja Mangkurawang adalah pasar yang cukup ramai dikunjungi oleh masyarakat yang umumnya masih menggunakan ragam kedaerahaan dalam berbahasa karena letaknya di tengah masyarakat yang beragam suku, bahasa, dan agamanya sehingga tidak jarang terjadi ragam bahasa campur kode.

Hal inilah yang menarik perhatian untuk diadakannya penelitian campur kode yang dikhususkan pada kalangan pedagang di Pasar Gerbang Raja Mangkurawang. Alasan lain yang mendasari dilakukan penelitian ini ialah karena

belum ada yang meneliti campur kode yang terjadi di tempat tersebut. Penelitian ini bertujuan untuk mengetahui penyisipan unsur-unsur satuan bahasa dalam campur kode yang ada di sana.

Berdasarkan latar belakang di atas, maka secara lebih khusus masalah yang dikaji dirumuskan sebagai berikut: (1) Bagaimana bentuk campur kode bahasa yang terjadi dalam interaksi jual beli di Pasar Gerbang Raja Mangkurawang?; (2) Faktor apa saja yang melatarbelakangi terjadinya campur kode bahasa yang terjadi dalam interaksi jual beli di Pasar Gerbang Raja Mangkurawang?

Teori-teori yang mendukung untuk menjelaskan konsep dalam penelitian ini, diantaranya teori tentang sosiolinguistik, peristiwa tutur, bilingualisme dan campur kode. Chaer dan Agustina (2010: 2), mendefinisikan sosiolinguistik adalah ilmu antardisiplin antara sosiologi dan linguistik. Sosiologi adalah kajian yang objektif dan ilmiah mengenai manusia di dalam masyarakat. Sedangkan, linguistik adalah bidang ilmu yang mengambil bahasa sebagai objek penelitiannya. Dengan demikian, secara mudah dapat dikatakan bahwa sosiolinguistik adalah bidang ilmu antardisiplin yang mempelajari bahasa dalam kaitannya dengan penggunaan bahasa itu di dalam masyarakat.

Chaer dan Agustina (2010: 47) mendefinisikan peristiwa tutur adalah terjadinya atau berlangsungnya interaksi linguistik dalam satu bentuk ujaran atau yang melibatkan dua pihak, yaitu penutur dan lawan tutur, dengan satu pokok tuturan, di dalam waktu, tempat dan situasi tertentu. Seiring perkembangan zaman yang terus mengalami kemajuan, penggunaan bahasa di lingkungan masyarakat juga mengalami perkembangan. Saat ini sangat jarang ditemui masyarakat yang hanya menguasai satu bahasa saja. Hal ini dikarenakan adanya interaksi sosial budaya dalam masyarakat yang memungkinkan adanya asimilasi kebudayaan dari masyarakat yang memiliki latar belakang yang berbeda-beda yang mengakibatkan banyaknya bahasa yang beredar di masyarakat.

Mackey dan Fishman (dalam Chaer dan Agustina, 2010: 84) mengemukakan bilingualisme ialah penggunaan dua bahasa oleh seorang penutur dalam pergaulannya dengan orang lain secara bergantian. Untuk bisa menggunakan dua bahasa tentunya seseorang harus menguasai bahasa pertama atau bahasa ibu (B1) dan yang kedua ialah bahasa lain (B2).

Lebih lanjut, Bloomfield (dalam Chaer dan Agustina, 2010: 85) mengatakan "bilingualisme adalah kemampuan seorang penutur untuk menggunakan dua bahasa dengan sama baiknya". Jadi, menurut Bloomfied seseorang bisa disebut bilingual apabila dapat menggunakan B1 dan B2 dengan derajat yang sama baiknya.

Dari pengertian di atas, bisa disimpulkan bahwa bilingualisme adalah kemampuan seseorang penutur untuk menggunakan dua bahasa dalam berinteraksi.

Campur kode atau dalam bahasa Inggris disebut code mixing. Sumarsono (2014: 202) menjelaskan campur kode adalah suatu kondisi di mana penutur menyelipkan unsur-unsur bahasa lain ketika sedang memakai bahasa tertentu. Seorang penutur misalnya, dalam berinteraksi menggunakan bahasa Indonesia tetapi pada katakata tertentu menyelipkan serpihan bahasa daerahnya, bisa dikatakan penutur tersebut telah melakukan campur kode.

Lebih lanjut, Fasold (dalam Chaer dan Agustina, 2010: 115) campur kode ialah bila seseorang menggunakan satu kata atau frasa dari satu bahasa, berarti telah melakukan campur kode. Nababan (dalam Aslinda dan Syafyahya, 2014: 87) mengatakan campur kode bisa terjadi bila mana seseorang mencampurkan dua atau lebih bahasa atau ragam bahasa dalam suatu tindakan berbahasa tanpa ada seseuatu dalam situasi berbahasa yang menuntut pencampuran bahasa. 
Situasi nonformal atau kesantaian merupakan ciri yang menonjol dalam campur kode.

Selanjutnya Berdasarkan unsur-unsur kebahasaan yang terlibat di dalamnya, Suwito (dalam Yulianti, 2015: 19-20) membagi wujud campur kode menjadi beberapa, antara lain: (1) penyisipan unsur-unsur yang berwujud kata; (2) penyisipan unsur-unsur yang berwujud frasa; (3) penyisipan unsur-unsur yang berwujud idiom atau ungkapan; (4) penyisipan unsur-unsur yang berwujud baster; (5) penyisipan unsur-unsur yang berwujud pengulangan kata; dan (6) penyisipan unsur-unsur yang berwujud klausa.

Faktor yang melatarbelakangi terjadinya campur kode Kanchru (dalam Marni, 2016: 5) digolongkan menjadi dua, yaitu: (1) sikap (attitudinal type) yaitu sikap latar belakang penutur; (2) kebahasaan (linguistic type) yaitu latar belakang keterbatasan bahasa.

Penelitian ini melakukan penyelidikan mengenai campur kode yang termasuk dalam

bidang sosiolinguistik. Campur kode adalah punggunaan dua kode bahasa atau lebih oleh seorang penutur dalam suatu tindakan berbahasa. Campur kode biasanya terjadi pada situasi nonformal dan biasanya tanpa disadari oleh seorang penutur, sebab terjadi secara spontan. Hal lain yang bisa juga menyebabkan campur kode dalam berbahasa ialah karena seorang penutur terbiasa menggunakan dua bahasa dalam berkomunikasi.

\section{METODE PENELITIAN}

Penelitian ini dilakukan di Pasar Gerbang Raja Mangkurawang kecamatan Tenggarong, pada bulan Maret sampai April 2021. Penelitian ini digolongkan ke dalam jenis penelitian kualitatif, di mana penelitian yang menghasilkan data deskriptif berupa kata-kata tertulis dan bukan angka.

Lofland dan Loflan (dalam Moleong, 2012: 157) sumber data utama dalam penelitian kualitatif ialah kata-kata dan tindakan, selebihnya adalah data tambahan seperti dokumen dan lain-lain. Sumber data bisa juga diartikan sebagai subjek penelitian. Sumber data dalam penelitian ini ialah para pedagang yang melakukan transaksi jual beli di Pasar Gerbang Raja Mangkurawang.

Langkah awal yang dilaksanakan dalam pengumpulan data yaitu melakukan observasi.
Kegiatan observasi ini bertujuan untuk melakukan pengamatan tertentu pada objek penelitian. Adapun teknik lanjutan untuk pengumpulan data dalam penelitian ini sebagai berikut: (1) teknik simak, yaitu pengumpulan data dengan cara menyimak secara langsung pemakaian bahasa lisan yang digunakan oleh pedagang di Pasar Gerbang Raja Mangkurawang kecamatan Tenggarong; (2) teknik rekam, dilakukan dengan cara merekam pemakaian bahasa lisan pedagang dengan memakai alat perekam suaru berupa telepon genggam (handphone); (3) teknik wawancara, digunakan pada tahap penyediaan data yang dilakukan dengan cara melakukan percakapan dengan penutur yang telah dipilih sebagai informan. Percakapan yang dilakukan dengan informan hanya terkait identitas diri saja yaitu meliputi: nama, jenis kelamin, usia, alamat, pendidikan terakhir dan suku. Setelah data terkumpul, data dianalisis menggunakan metode kontekstual.

\section{HASIL DAN PEMBAHASAN Bentuk Campur Kode}

Temuan hasil dalam penelitian ini secara garis besar berkaitan dengan aspek kebahasaan yang terjadi dalam interaksi jual beli di Pasar Gerbang Raja Mangkurawang kecamatan Tenggarong. Hasil penelitian ini mengungkapkan temuan bentuk-bentuk campur kode berupa penyisipan unsur-unsur kata, frasa dan klausa. Selanjutnya, ditemukan pula faktor-faktor yang melatarbelakangi terjadinya campur kode di kalangan pedagang yaitu: (1) faktor penutur yaitu campur kode yang terjadi karena kesantaian dan kebiasaan dalam berbahasa; dan (2) faktor kebahasaan yaitu campur kode yang terjadi karena keterbatasan bahasa dan para pedagang menganggap kata dari bahasa daerahnya lebih halus untuk digunakan dalam kegiatan interaksi jual beli.

Berdasarkan hasil penelitian di lapangan yang difokuskan pada pedagang di Pasar Gerbang Raja Mangkurawang kecamatan Tenggarong. Dari hasil pengamatan yang dilakukan, diketahui bahwa para pedagang di pasar tersebut memiliki beragam suku. Suku yang mayoritas berdagang di Pasar Gerbang Raja Mangkurawang adalah suku Kutai dan Jawa. Keberadaan suku Kutai tidak terlepas dari bahasa yang mereka gunakan seharihari. Maksudnya, mereka sering berkomunikasi 
dengan menyisipkan unsur bahasa Kutai berupa kata, frasa, dan klausa ke dalam bahasa Indonesia.

Hasil penelitian ini adalah bentuk campur kode dan faktor yang melatarbelakangi terjadinya campur kode dalam interaksi jual beli di kalangan pedagang Pasar Gerbang Raja Mangkurawang kecamatan Tenggarong. Hal ini bisa dilihat sebagai berikut.

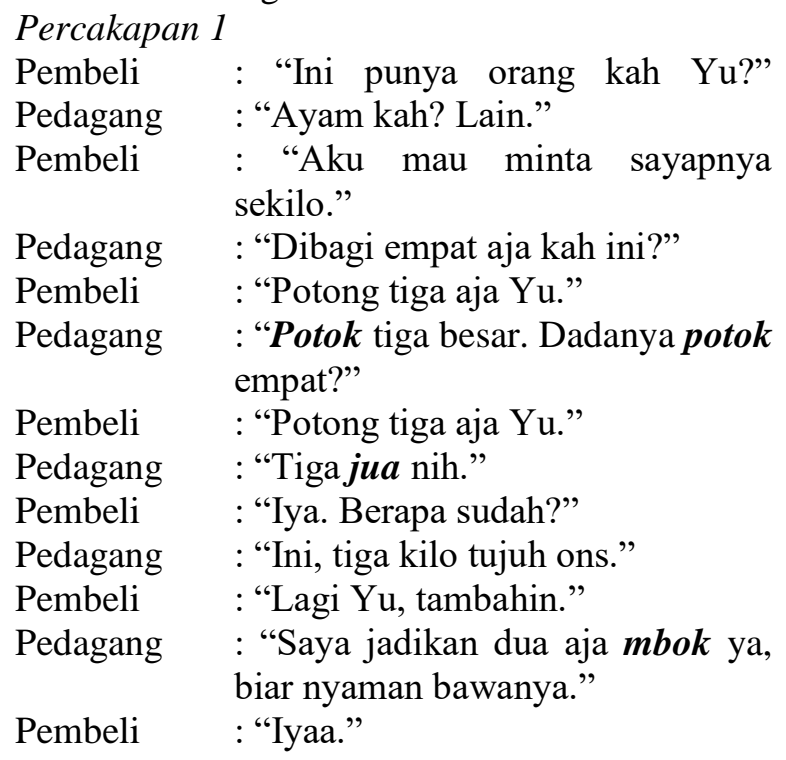

Data di atas merupakan data yang berasal dari kegiatan jual beli yang dilakukan oleh pedagang dan pembeli di Pasar Gerbang Raja Mangkurawang, pada lapak pedagang ayam. Pedagang berjenis kelamin perempuan, yang berusia 32 tahun dengan tingkat pendidikan Sekolah Menengah Pertama (SMP). Selanjutnya, pembeli tersebut berjenis kelamin perempuan.

Berdasarkan bentuknya, campur kode yang dilakukan adalah campur kode berbentuk kata, yaitu: potok yang memiliki arti 'potong', kata jua yang memiliki arti 'juga', dan kata mbok yang memiliki arti 'tante' pada tuturan pedagang. Disebut kata, karena potok, jua dan mbok merupakan satuan bahasa yang dapat berdiri sendiri dan merupakan satuan terkecil dari bahasa yang memiliki arti dan makna.

\section{Percakapan 2}

$\begin{array}{ll}\text { Pembeli } & \text { : "Lima ribu ya? Takutnya hak" } \\ \text { Pedagang } & \text { : Nggih." } \\ \text { Pembeli } & \text { :"Labunya } 3 \text { ribu." } \\ \text { Pedagang } & \text { : "Bayamnya?" } \\ \text { Pembeli } & \text { : "Endik, aku tadi beli itu." }\end{array}$

Pedagang : "Apalagi? Delapan ribu."

Pembeli : "Cabeknya."

Pedagang : "Berapa, lima ribu?"

Pembeli : "Aku nih endak nyimpan, soalnya cabek ku maseh banyak."

Pedagang : "Atau yang tuh sepuluh ribu seons, cantik."

Pembeli : "Iya hak, sepuluh ribu."

Data di atas merupakan data yang berasal dari kegiatan jual beli yang dilakukan oleh pedagang dan pembeli di Pasar Gerbang Raja Mangkurawang, pada lapak pedagang sayur. Pedagang berjenis kelamin perempuan, yang berusia 55 tahun dengan tingkat pendidikan Sekolah Dasar (SD). Selanjutnya, pembeli tersebut berjenis kelamin perempuan.

Berdasarkan bentuknya, campur kode yang dilakukan adalah campur kode berbentuk kata, yaitu kata bahasa Indonesia yang menyisip ke dalam bahasa Kutai. Hal tersebut dapat dibuktikan pada kata 'cantik'. Kata tersebut menunjukkan bahwa terjadinya campur kode bentuk kata bahasa Indonesia ke dalam bahasa Kutai pada peristiwa tutur tersebut.

\section{Percakapan 3}

$\begin{array}{ll}\text { Pembeli } & \text { : "Ikan ininya setengah kilo." } \\ \text { Pedagang } & : \text { "Apa pak de, yang kecil?" } \\ \text { Pembeli } & : \text { "Iya." }\end{array}$

$\begin{array}{ll}\text { Pedagang } & \text { : "Kendia endik pak de?" } \\ \text { Pembeli } & : \text { "Nggak, aku ada bawa." } \\ \text { Pedagang } & : \text { "Tiga lima pak de." } \\ \text { Pembeli } & \text { : "Iya, makasih." }\end{array}$

Data di atas merupakan data yang berasal dari kegiatan jual beli yang dilakukan oleh pedagang dan pembeli di Pasar Gerbang Raja Mangkurawang, pada lapak pedagang ikan sungai. Pedagang berjenis kelamin perempuan, yang berusia 48 tahun dengan tingkat pendidikan Sekolah Menegah Atas (SMA). Selanjutnya, pembeli tersebut berjenis kelamin laki-laki.

Berdasarkan bentuknya, campur kode yang dilakukan adalah campur kode berbentuk kata, yaitu kata kendia yang memiliki arti 'nama jenis ikan sungai yang bentuknya seperti ikan mas, tetapi kecil' dan kata endik yang memiliki arti 'tidak' pada tuturan pedagang. Disebut kata, karena kendia dan endik merupakan satuan bahasa yang dapat berdiri sendiri dan merupakan satuan terkecil dari bahasa yang memiliki arti dan makna. 


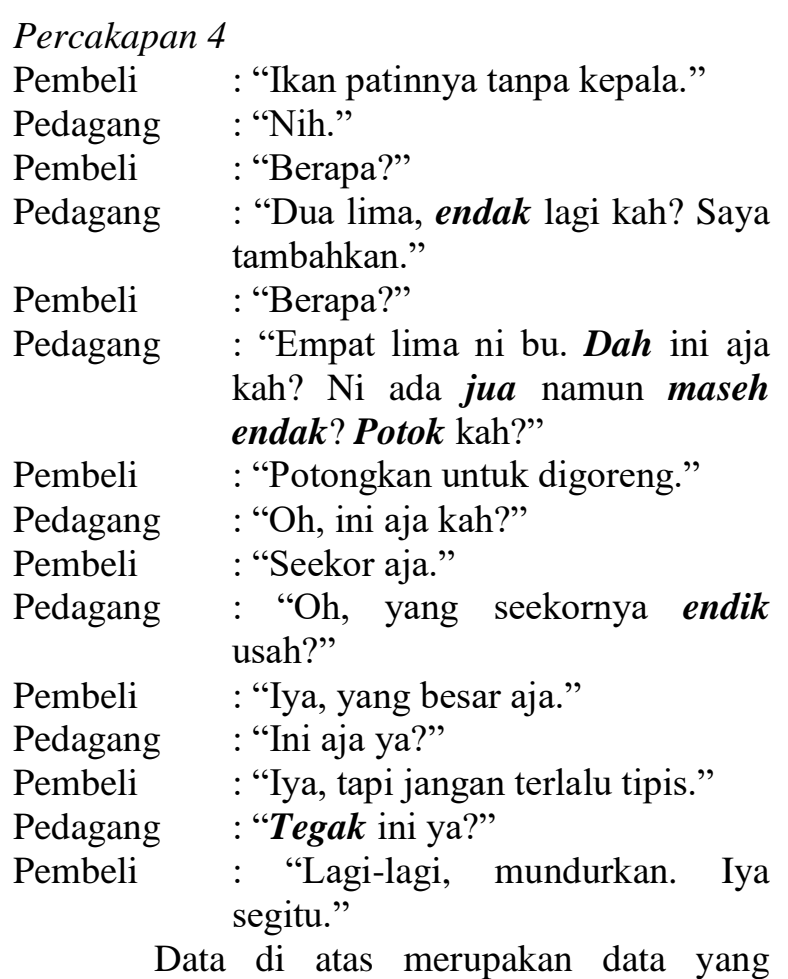
berasal dari kegiatan jual beli yang dilakukan oleh pedagang dan pembeli di Pasar Gerbang Raja Mangkurawang, pada lapak pedagang ikan sungai. Pedagang berjenis kelamin perempuan, yang berusia 45 tahun dengan tingkat pendidikan Sekolah Menegah Pertama (SMP). Selanjutnya, pembeli tersebut berjenis kelamin perempuan.

Berdasarkan bentuknya, campur kode yang dilakukan adalah campur kode berbentuk

kata dan frasa, yaitu; kata endak yang memiliki arti 'mau', kata dah yang memiliki arti 'sudah', kata jua yang memiliki arti 'juga', kata potok yang memiliki arti 'potong', kata endik yang memiliki arti 'tidak', kata tegak yang memiliki arti 'seperti', dan frasa maseh endak yang memiliki arti 'masih mau'. Disebut kata, karena endak, dah, jua, potok, endik, dan tegak merupakan satuan bahasa yang dapat berdiri sendiri dan merupakan satuan terkecil dari bahasa yang dapat berdiri sendiri dan merupakan satuan terkecil dari bahasa yang memiliki arti atau makna. Kemudian, disebut frasa, karena maseh endak merupakan gabungan dua buah kata yang sifatnya tidak predikat dan tidak melebihi batas fungsi unsur klausa.

\section{Percakapan 5}

Pedagang : "Apa bu?"
Pembeli : "Ada tepung gandum yang biasa aja kah?"

Pedagang : "Ada, berapa kita endak?"

Pembeli : "Berapa sekilo?"

Pedagang : "Sekilo tujuh ribu alak dua kilo tiga belas ribu."

Pembeli : "Sekilo aja."

Data di atas merupakan data yang berasal dari kegiatan jual beli yang dilakukan oleh pedagang dan pembeli di Pasar Gerbang Raja Mangkurawang, pada kios pedagang sembako. Pedagang berjenis kelamin perempuan, yang berusia 45 tahun dengan tingkat pendidikan Sekolah Menegah Atas (SMA). Selanjutnya, pembeli tersebut berjenis kelamin perempuan.

Berdasarkan bentuknya, campur kode yang dilakukan adalah campur kode berbentuk kata, yaitu kata kita yang memiliki arti 'kamu (tetapi untuk orang yang lebih tua)', kata endak yang memiliki arti 'mau', dan kata alak yang memiliki arti 'ambil'. Disebut kata, karena kita, endak, dan alak merupakan satuan terkecil dari bahasa yang memiliki arti atau makna.

\section{Percakapan 6}

Pembeli : "Lolipop nih berapa?"

Pedagang : "Dua puluh satu"

Pembeli : "Korek kayu berapa Om?"

Pedagang : "Tiga lima se-pack."

Pembeli : "Sudah Om ini aja."

Pedagang : "Bentar ya."

Pembeli : "Om, ini tiga sepuluh ribu nggak bisa kah?"

Pedagang : "Hah... Sembarang sebut. Tiga sepuluh?

Pembeli : "Iya Om."

\section{Pedagang : "Endik bisa leh".}

Data di atas merupakan data yang berasal dari kegiatan jual beli yang dilakukan oleh pedagang dan pembeli di Pasar Gerbang Raja Mangkurawang, pada kios pedagang sembako. Pedagang berjenis kelamin laki-laki, yang berusia 49 tahun dengan tingkat pendidikan Sekolah Menegah Atas (SMA). Selanjutnya, pembeli tersebut berjenis kelamin perempuan.

Berdasarkan bentuknya, campur kode yang dilakukan adalah campur kode berbentuk kata dan frasa, yaitu; kata endik yang memiliki arti 'tidak' dan frasa sembarang sebut yang memiliki arti 'asal mengatakan'. Disebut kata, karena endik merupakan satuan bahasa yang dapat berdiri 
sendiri dan merupakan satuan terkecil dari bahasa yang memiliki arti atau makna. Kemudian disebut frasa, karena sembarang sebut merupakan gabungan dua buah kata yang sifatnya tidak predikat dan tidak melebihi batas fungsi unsur klausa.

\section{Percakapan 7}

$\begin{array}{ll}\text { Pembeli } & \text { : "Dijual laris?" } \\ \text { Pedagang } & \text { :"Laris." } \\ \text { Pembeli } & \text { :"Berapa se-pack?" } \\ \text { Pedagang } & \text { :"Dua puluh ribu, isi dua belas." } \\ \text { Pembeli } & \text { :"Berarti jualnya dua ribu." } \\ \text { Pedagang } & \text { :"Tiga ribu, namun endak cepat } \\ & \text { naik haji." } \\ \text { Pembeli } & \text { :"Amin." } \\ \text { Pedagang } & \text { : "Kanak-kanak tuh gawal yang } \\ & \text { ada sumpit-sumpitnya." } \\ \text { Pembeli } & \text { :"Iya." }\end{array}$

Data di atas merupakan data yang berasal dari kegiatan jual beli yang dilakukan oleh pedagang dan pembeli di Pasar Gerbang Raja Mangkurawang, pada kios pedagang sembako. Pedagang berjenis kelamin perempuan, yang berusia 45 tahun dengan tingkat pendidikan Sekolah Menegah Atas (SMA). Selanjutnya, pembeli tersebut berjenis kelamin perempuan.

Berdasarkan bentuknya, campur kode yang dilakukan adalah campur kode berbentuk kata, yaitu; kata endak yang memiliki arti 'mau', dan kata gawal yang memiliki arti 'suka' pada tuturan pedagang. Disebut kata, karena endak dan gawal merupakan satuan bahasa yang dapat berdiri sendiri dan merupakan satuan terkecil dari bahasa yang memiliki arti atau makna.

\section{Percakapan 8}

Pembeli : "Berapa?"

Pedagang : "Keli ada yang dua puluh, dua lima, tiga puluh."

Pembeli : "Yang dua lima itu aja."

Pedagang : "Nih yang pore."

Pembeli : "Makasih ya."

Data di atas merupakan data yang berasal dari kegiatan jual beli yang dilakukan oleh pedagang dan pembeli di Pasar Gerbang Raja Mangkurawang, pada lapak pedagang ikan sungai. Pedagang berjenis kelamin perempuan, yang berusia 46 tahun dengan tingkat pendidikan
Sekolah Dasar (SD). Selanjutnya, pembeli tersebut berjenis kelamin perempuan.

Berdasarkan bentuknya, campur kode yang dilakukan adalah campur kode berbentuk kata, yaitu; keli yang memiliki arti 'ikan lele', dan kata pore yang memiliki arti 'besar' pada tuturan pedagang. Disebut kata, karena keli dan pore merupakan satuan bahasa yang dapat berdiri sendiri dan merupakan satuan terkecil dari bahasa yang memiliki arti atau makna.

\section{Percakapan 9}

Pembeli : "Milku habis kah?"

Pedagang : "Apa itu?"

Pembeli : "Milku-milku."

Pedagang : "Milku ada sayang."

Pembeli : "Yang coklat ada kah Cil?"

Pedagang : : "Ada, setumat ya."

Pembeli : "Minta tiga. Mana milku-nya?"

Pedagang : "Itu. Nih, kresek. Awak bawak tegak itu maha kah?

Pembeli : "Makasih Cil."

Data di atas merupakan data yang berasal dari kegiatan jual beli yang dilakukan oleh pedagang dan pembeli di Pasar Gerbang Raja Mangkurawang, pada kios pedagang sembako. Pedagang berjenis kelamin perempuan, yang berusia 45 tahun dengan tingkat pendidikan Sekolah Menegah Atas (SMA). Selanjutnya, pembeli tersebut berjenis kelamin perempuan.

Berdasarkan bentuknya, campur kode yang dilakukan adalah campur kode berbentuk kata dan klausa, yaitu kata setumat yang memiliki arti 'sebentar', kata kresek yang memiliki arti 'plastik', kata tegak yang memiliki arti 'seperti', kata maha yang memiliki arti 'saja', dan klausa awak bawak yang memiliki arti 'kamu bawa' pada tuturan pedagang. Disebut kata, karena setumat, kresek, tegak, dan maha merupakan satua bahasa yang dapat berdiri sendiri dan merupakan satuan terkecil dari bahasa yang memiliki arti atau makna. Sedangkan awak bawak disebut klausa karena terdiri dari kata awak yang menduduki

fungsi subjek dan kata bawak yang menduduki fungsi predikat.

\section{Percakapan 10}

Pembeli : "Ada pahanya kah Om?"

Pedagang : "Nggak ada sudah pahanya ini, yang ncari paha nggak ada." 
Pembeli : "Habis kah sudah ayamnya Om?" Pedagang : "Sisa ini yang di atas meja. Kita berapa kilo? Mau disisihkan memang."

$\begin{array}{ll}\text { Pembeli } & \text { : "Saya setengah aja Om." } \\ \text { Pedagang } & \text { :"Kita berapa?" } \\ \text { Pembeli } & \text { :"Seadaanya." } \\ \text { Pedagang } & \text { :"Seadaanya, kayak mana?" } \\ \text { Pembeli } & \text { :"Dua atau satu." } \\ \text { Pedagang } & \text { :"Dua dada? Dua dada lebih dua } \\ & \text { kilo. Besar ayamnya ini." } \\ \text { Pembeli } & \text { :"Iya Om." }\end{array}$

Data di atas merupakan data yang berasal dari kegiatan jual beli yang dilakukan oleh pedagang dan pembeli di Pasar Gerbang Raja Mangkurawang, pada lapak pedagang ayam. Pedagang berjenis kelamin laki-laki, yang berusia 38 tahun dengan tingkat pendidikan Sekolah Menegah Atas (SMA). Selanjutnya, pembeli tersebut berjenis kelamin perempuan.

Berdasarkan bentuknya, campur kode yang dilakukan adalah campur kode berbentuk kata, yaitu kata ncari yang memiliki arti 'cari', dan kata kita yang memiliki arti 'kamu (tetapi untuk orang yang lebih tua) pada tuturan pedagang. Disebut kata, karena ncari dan kita merupakan satuan bahasa yang dapat berdiri sendiri dan merupakan satuan terkecil dari bahasa yang memiliki arti atau makna.

\begin{tabular}{|c|c|}
\hline \multicolumn{2}{|c|}{ Percakapan 11} \\
\hline Pedagang & : “Jagungnya Mbak?” \\
\hline Pembeli & : "Berapaan?" \\
\hline Pedagang & :"Sepuluh ribu setumpuk." \\
\hline Pembeli & :"Ini Bule." \\
\hline Pedagang & : "Satu aja?" \\
\hline Pembeli & : "Iya." \\
\hline Pedagang & $\begin{array}{l}\text { : "Apa lagi? Kecambah, tempe, } \\
\text { tahu nggak?" }\end{array}$ \\
\hline Pembeli & : "Nggak." \\
\hline Pedagang & : "Makasih ya." \\
\hline
\end{tabular}

berasal dari kegiatan jual beli yang dilakukan oleh pedagang dan pembeli di Pasar Gerbang Raja Mangkurawang, pada lapak pedagang

sayur. Pedagang berjenis kelamin perempuan, yang berusia 55 tahun dengan tingkat pendidikan Sekolah Dasar (SD). Selanjutnya, pembeli tersebut berjenis kelamin perempuan.
Berdasarkan bentuknya, campur kode yang dilakukan adalah campur kode berupa kata, yaitu kata kecambah yang memiliki arti 'tauge' pada tuturan pedagang. Disebut kata, karena kecambah merupakan satuan bahasa yang dapat berdiri sendiri dan merupakan satuan terkecil dari bahasa yang memiliki arti atau makna.

\section{Percakapan 12}

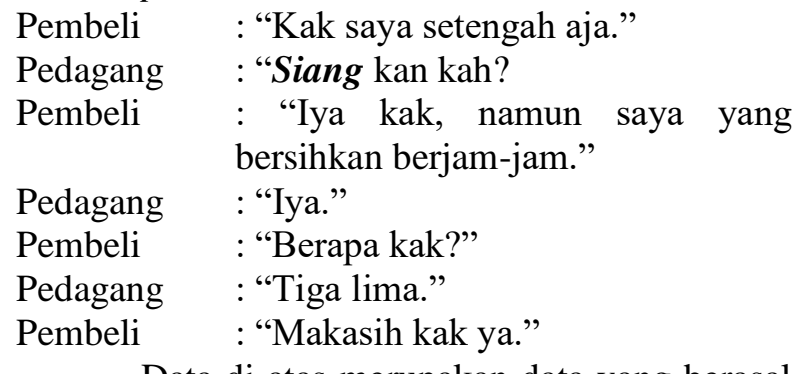

Data di atas merupakan data yang berasal dari kegiatan jual beli yang dilakukan oleh pedagang dan pembeli di Pasar Gerbang Raja Mangkurawang, pada lapak pedagang ikan sungai. Pedagang berjenis kelamin perempuan, yang berusia 48 tahun dengan tingkat pendidikan Sekolah Menegah Atas (SMA). Selanjutnya, pembeli tersebut berjenis kelamin perempuan.

Berdasarkan bentuknya, campur kode yang dilakukan adalah campur kode berbentuk kata, yaitu kata siang yang memiliki arti 'bersih' pada tuturan pedagang. Disebut kata, karena siang merupakan satuan bahasa yang dapat berdiri sendiri dan merupakan satuan terkecil dari bahasa yang memiliki arti atau makna.

\begin{tabular}{|c|c|}
\hline \multicolumn{2}{|c|}{ Percakapan 13} \\
\hline Pedagang & : "Berapa kita donat tadi?" \\
\hline Pembeli & : "Empat puluh, ada kah?” \\
\hline Pedagang & :"Dua puluh aja Bu." \\
\hline Pembeli & : "Tambah ini aja." \\
\hline Pedagang & : “Paskan empat puluh kah?” \\
\hline Pembeli & 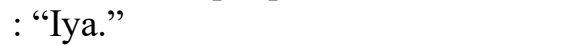 \\
\hline Pedagang & : “Apa lagi? Gogos kah?” \\
\hline Pembeli & : "Ada berapa?" \\
\hline Pedagang & : "Ada tiga belas maha." \\
\hline Pembeli & $\begin{array}{l}\text { : "Bentar dulu, tanya Bule ada } \\
\text { berapa." }\end{array}$ \\
\hline Pedagang & : “Ada kah?” \\
\hline Pembeli & $\begin{array}{l}\text { : "Bule ada lima belas. Ya sudah } \\
\text { tambahkan aja tadi, jadikan tiga } \\
\text { puluh." }\end{array}$ \\
\hline edagang & :"Iyaа." \\
\hline
\end{tabular}

Pembeli : "Berapa?" 


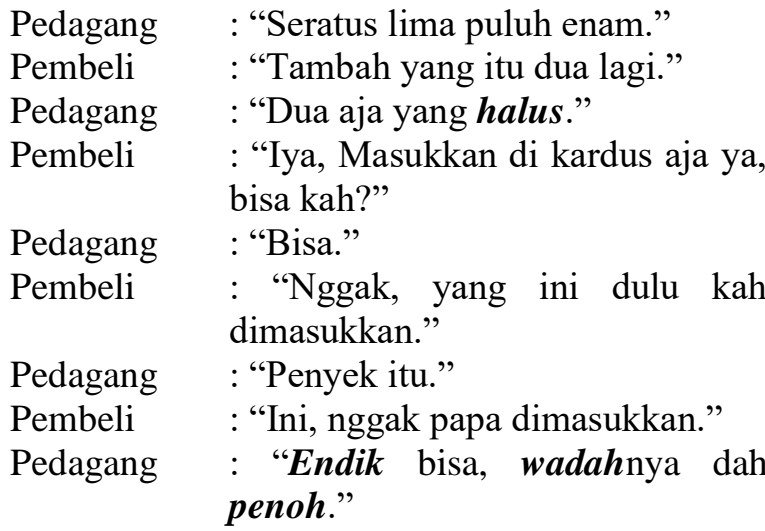

Data di atas merupakan data yang berasal dari kegiatan jual beli yang dilakukan oleh pedagang dan pembeli di Pasar Gerbang Raja Mangkurawang, pada lapak pedagang kue tradisional. Pedagang berjenis kelamin perempuan, yang berusia 43 tahun dengan tingkat pendidikan Sekolah Menegah Atas (SMA). Selanjutnya, pembeli tersebut berjenis kelamin perempuan.

Berdasarkan bentuknya, campur kode yang dilakukan adalah campur kode berbentuk kata, yaitu kata kita yang memiliki arti 'kamu (tetapi untuk orang yang lebih tua)', kata gogos yang memiliki arti 'lemper', kata halus yang memiliki arti 'kecil', kata endik yang memiliki arti 'tidak', kata wadah yang memiliki arti 'tempat', dan kata penoh yang memiliki arti 'penuh' pada tuturan pedagang. Disebut kata, karena kita, gogos, halus, endik, wadah, dan penoh merupakan satuan bahasa yang dapat berdiri sendiri dan merupakan satuan terkecil dari bahasa yang memiliki arti atau makna.

\section{Percakapan 14}

Pedagang : "Mbok tolong jua tangkapkan jukut nila tuh, tama-kan ke situ."

Pembeli : "Oh, tangkapkan."

Pedagang : "Iya."

Pembeli : "Eh, terima kasih."

Pedagang : "Aku terima kasih."

Pembeli : "Latah ku."

Data di atas merupakan data yang berasal dari kegiatan jual beli yang dilakukan oleh pedagang dan pembeli di Pasar Gerbang Raja Mangkurawang, pada lapak pedagang ikan sungai. Pedagang berjenis kelamin perempuan, yang berusia 45 tahun dengan tingkat pendidikan Sekolah Menegah Pertama (SMP). Selanjutnya, pembeli tersebut berjenis kelamin perempuan.

Berdasarkan bentuknya, campur kode yang dilakukan adalah campur kode berbentuk kata, yaitu kata mbok yang memiliki arti 'tante', kata jua yang memiliki arti 'juga', kata jukut yang memiliki arti 'ikan', dan kata tama yang memiliki arti 'masuk' pada tuturan pedagang. Disebut kata, karena mbok, jua, jukut, dan tama merupakan satuan bahasa yang dapat berdiri sendiri dan merupakan satuan terkecil dari bahasa yang memiliki arti atau makna.

\section{Percakapan 15}

Pembeli : "Lepok nih berapa?"

Penjual : "Nih dua puluh lima, empat puluh, lima puluh. Kepala alak buang?"

Pembeli : "Biarkan endik usah di anu kin, tahu aja kami."

Penjual : "Endik usah, tegak ni aja?"

Pembeli : "Iyaa."

Data di atas merupakan data yang berasal dari kegiatan jual beli yang dilakukan oleh pedagang dan pembeli di Pasar Gerbang Raja Mangkurawang, pada lapak pedagang ikan sungai. Pedagang berjenis kelamin perempuan, yang berusia 32 tahun dengan tingkat pendidikan Sekolah Menengah Pertama (SMP). Selanjutnya, pembeli tersebut berjenis kelamin perempuan. Berdasarkan bentuknya, campur kode yang dilakukan adalah campur kode berbentuk kata, yaitu kata bahasa Indonesia yang menyisip ke dalam bahasa Kutai. Hal tersebut dapat dibuktikan pada kata 'kepala' dan 'aja'. Kata tersebut menunjukkan bahwa terjadinya campur kode bentuk kata bahasa Indonesia ke dalam bahasa Kutai pada peristiwa tutur tersebut.

\section{Faktor Penyebab Campur Kode Faktor Penutur}

Faktor penutur yang melatarbelakangi terjadinya campur kode, yaitu; 1) karena kesantaian dan kebiasaan sehari-hari yang menggunakan bahasa daerah, dan 2) latar belakang pendidikan penutur.

\section{Faktor Kebahasaan}

Faktor kebahasaan yang menyebabkan terjadinya campur kode karena keterbatasan bahasa yang dikuasai dan penutur menganggap kata dari bahasanya sendiri (bahasa daerah) lebih halus, seperti kata kita yang memiliki arti 'kamu' (sapaan kepada orang lebih tua atau yang dihormati). Contohnya sebagai berikut.

Pedagang : "Apa bu?" 
Pembeli : "Ada tepung gandum yang biasa aja kah?"

Pedagang : "Ada, berapa kita endak?"

Pembeli : "Berapa sekilo?"

Pedagang : "Sekilo tujuh ribu alak dua kilo tiga belas ribu."

Pembeli : "Sekilo aja."

Digunakannya kita karena kata tersebut dianggap lebih halus daripada kata awak yang sama-sama memiliki arti 'kamu'. Selain itu, kata kita juga sudah menjadi kebiasaan dalam berkomunikasi sehari-hari untuk menghormati orang yang lebih tua.

Tabel 1

Kata bahasa Kutai menyisip ke dalam bahasa Indonesia

\begin{tabular}{|c|c|c|c|}
\hline No & $\begin{array}{c}\text { Bahasa } \\
\text { Kutai }\end{array}$ & Arti & $\begin{array}{l}\text { Tulisan } \\
\text { Fonetis }\end{array}$ \\
\hline 1 & Alak & 'ambil' & [alak] \\
\hline 2 & $D a h$ & 'sudah' & [dah] \\
\hline 3 & Endak & 'mau' & [endak] \\
\hline 4 & Endik & 'tidak' & [endik] \\
\hline 5 & Gawal & 'suka' & [gawal] \\
\hline 6 & Gogos & 'lemper' & [gogos] \\
\hline 7 & Halus & 'kecil' & [halus] \\
\hline 8 & Jua & 'juga' & [jua] \\
\hline 9 & Jukut & ‘ikan' & [jukut] \\
\hline 10 & Kecambah & 'tauge' & [kecambah] \\
\hline 11 & Keli & 'ikan lele' & [keli] \\
\hline 12 & Kendia & $\begin{array}{l}\text { 'ikan sungai } \\
\text { (seperti ikan } \\
\text { mas)' }\end{array}$ & [kendia] \\
\hline 13 & Kita & $\begin{array}{l}\text { 'kamu (untuk } \\
\text { orang yang } \\
\text { lebih tua)' }\end{array}$ & [kita] \\
\hline 14 & Kresek & 'plastik' & [kresek] \\
\hline 15 & Maha & 'saja' & [maha] \\
\hline 16 & Mbok & 'tante' & [mbok] \\
\hline 17 & Ncari & 'cari' & [ncari] \\
\hline 18 & Penoh & 'penuh' & [penoh] \\
\hline 19 & Pore & 'besar' & [poré] \\
\hline 20 & Potok & 'potong' & [potok] \\
\hline 21 & Setumat & 'sebentar' & [setumat] \\
\hline 22 & Siang & ‘bersih’ & [siang] \\
\hline 23 & Tama & 'masuk' & [tama] \\
\hline 24 & Tegak & 'seperti' & [tegak] \\
\hline 25 & Wadah & 'tempat' & [wadah] \\
\hline
\end{tabular}

Tabel 2

Kata bahasa Indonesia menyisip ke dalam bahasa Kutai

\begin{tabular}{rccc}
\hline No & $\begin{array}{c}\text { Bahasa } \\
\text { Indonesia }\end{array}$ & Arti & $\begin{array}{c}\text { Tulisan } \\
\text { Fonetis }\end{array}$ \\
\hline 1 & Cantik & - & [cantik] \\
2 & Kepala & - & [kepala] \\
3 & Aja & - & [aja] \\
\hline
\end{tabular}

Tabel 3

Campur kode bentuk frasa

\begin{tabular}{|c|c|c|c|}
\hline No & $\begin{array}{c}\text { Bahasa } \\
\text { Kutai }\end{array}$ & Arti & $\begin{array}{l}\text { Tulisan } \\
\text { Fonetis }\end{array}$ \\
\hline 1 & Maseh endak & 'masih mau' & [maseh endak] \\
\hline 2 & $\begin{array}{c}\text { Sembarang } \\
\text { sebut }\end{array}$ & $\begin{array}{c}\text { 'asal } \\
\text { mengatakan' }\end{array}$ & $\begin{array}{c}\text { [sembarang } \\
\text { sebut] }\end{array}$ \\
\hline
\end{tabular}

Tabel 4

Campur kode bentuk klausa

\begin{tabular}{cccc}
\hline No & $\begin{array}{c}\text { Bahasa } \\
\text { Kutai }\end{array}$ & Arti & $\begin{array}{c}\text { Tulisan } \\
\text { Fonetis }\end{array}$ \\
\hline 1 & $\begin{array}{c}\text { Awak } \\
\text { bawak }\end{array}$ & 'kamu bawa' & [awak bawak] \\
\hline
\end{tabular}

\section{KESIMPULAN}

Berdasarkan hasil penelitian yang telah diperoleh, maka dapat disimpulkan. Bentuk satuan linguistik yang menyisip dalam tuturan di kalangan pedagang Pasar Gerbang Raja Mangkurawang kecamatan Tenggarong sebagai berikut.

\section{Bentuk Kata}

Penyisipan unsur kebahasan berupa kata terjadi dari bahasa Indonesia ke dalam bahasa Kutai maupun sebaliknya. Unsur yang menyisip dari bahasa Kutai dalam tuturan bahasa Indonesia, yaitu: alak 'ambil', dah 'sudah', endak 'mau', endik 'tidak', gawal 'suka', gogos 'lemper', halus 'kecil', jua 'juga', jukut 'ikan', kecambah 'tauge', keli 'ikan lele', kendia 'ikan sungai (seperti ikan mas)', kita 'kamu (untuk orang yang lebih tua)', kresek 'plastik', maha 'saja', mbok 'tante', ncari 'cari', penoh 'penuh', pore 'besar', potok 'potong', setumat 'sebentar', siang 'bersih', tama 'masuk', tegak 'seperti', wadah 'tempat'. Unsur yang menyisip dari bahasa Indonesia dalam tuturan bahasa Kutai, yaitu: cantik, kepada, aja.

\section{Bentuk Frasa}

Penyisipan unsur kebahasaan berupa frasa hanya ditemukan berupa penyisipan dari bahasa Kutai menyisip ke dalam tuturan bahasa Indonesia, yaitu: maseh endak 'masih mau', sembarang sebut 'asal mengatakan'.

\section{Bentuk Klausa}

Penyisipan unsur kebahasaan berupa klausa hanya ditemukan berupa penyisipan dari bahasa Kutai menyisip ke dalam tuturan bahasa Indonesia, yaitu: awak bawak 'kamu bawa'. 
Penyebab terjadinya campur kode bahasa Kutai dan bahasa Indonesia di kalangan pedagang Pasar Gerbang Raja Mangkurawang kecamatan Tenggarong terdiri dari dua faktor, yaitu faktor penutur dan faktor kebahasaan.

\section{UCAPAN TERIMA KASIH}

Penelitian ini dapat dilaksanakan dengan baik berkat bantuan dari berbagai pihak, untuk itu

peneliti ingin mengucapkan terima kasih kepada seluruh pedagang Pasar Gerbang Raja Mangkurawang kecamatan Tenggarong yang sudah bersedia menjadi informan dalam penelitian ini.

\section{REFERENSI}

Aslinda, dan Syafyahya Leni. (2014). Pengantar Sosiolinguistik. Bandung: PT Refika Aditama.

Chaer, Abdul, dan Leonie Agustina. (2010). Sosiolinguistik: Perkenalan Awal. Jakarta: Rineka Cipta.

Kridalaksana, Harimurti. (1982). Kamus Linguistik. Jakarta: PT Gramedia.

Marni, Wa Ode. (2016). Campur Kode dan Alih Kode dalam Peristiwa Jual Beli di Pasar Labuan Tobelo Kecamatan Wakorumba Utara Kabupaten Buton Utara. Jurnal Bastra. 02 (01). $1-15$.

Moleong. Lexy J. (2012). Metodologi Penelitian Kualitatif. Bandung: PT Remaja Rosdakarya.

Sumarsono. (2014). Sosiolinguistik. Yogyakarta: Sabda (Lembaga Studi Agama, Budaya dan Perdamaian).

Yulianti, Andi Indah. (2015). Campur Kode Bahasa Dayak Nganju dan Bahasa Indonesia pada Kicauan Twitter Remaja di Palangkaraya. Jurnal Kandai. 11 (01). 15-28. 